\title{
THE IMPACT OF INSTITUTIONS ON SERVICES EXPORTS OF CENTRAL AND EASTERN EUROPEAN COUNTRIES
}

\author{
Oleksandr Shnyrkov ${ }^{1}$, Rita Zablotska ${ }^{2}$, Oleksii Chugaiev ${ }^{3}$
}

\begin{abstract}
Besides labor, capital and technology, institutions are another important factor of production and exports. They set a framework of motivation for economic activities and their efficiency. The previous research provided evidence for the effect of institutions on international trade and development. This paper focuses on the effect of institutional progress on export competitiveness of several services sectors in Central and Eastern Europe in the post-crisis period (2011-2017). In the analyzed period the services exports growth turned out to be more stable than the goods exports growth. The multi-country models showed that several types of institutional improvements affected the exports growth in the medium run. Excluding outliers, using weighted enlarged sample and alternative method for measuring exports growth were applied to assess robustness of the research results. Labor force growth, GDP and GDP per capita were initially used as control variables, but in most cases their effect for exports growth was insignificant in Central and Eastern Europe. Sector specific approach to the analysis turned out to be the most effective to understand the transmission mechanism of the effect under the situation of services heterogeneity. Monetary freedom (currency stability and market-based prices) stimulates exports of transport services. The rule of law (contract enforcement, property rights, efficiency of police and courts, absence of crime and violence etc.) is important for raising international tourism receipts. Information and communication technologies services exports depend primarily on voice and accountability (democratic principles, respects human rights and free media). As for financial and insurance services exports, no significant institutional factor was found. Control of corruption, political stability, labor freedom, government integrity, government effectiveness and lower government size also may be important, but their effect is not robust or cannot be distinguished from the effect of the abovesaid factors. It is more likely that fighting corruption may have a positive impact on the services exports than on the goods exports. The latter depend positively on the level of investment freedom. Using the selected EU Member States in Central and Eastern Europe as a benchmarking level enabled us to estimate a potential effect for services exports in case of Ukraine if it reaches their level of institutional development. In particular the institutional progress can boost Ukrainian transport, tourism, information and communication technologies services exports by $30-200 \%$ or by $10-15 \%$ of its GDP.
\end{abstract}

Key words: institutions, business regulation, international trade, services exports, Central and Eastern Europe.

JEL Classification: F14, L80, P48

\section{Introduction}

The interaction mechanism for exports and institutions can be specified in the following way. Development of foreign economic relations is determined by intensiveness of physical and human capital accumulation, and labor productivity growth. The latter depends on technological development and raising production efficiency as a result of participation of a national economy in the international division of labor. Technological progress is faster under favorable conditions for economic entities and efficient motivation for innovation and research activities. The stimuli for this depend on institutions existing in a society. Therefore competitiveness of domestic producers of goods and services depends

\footnotetext{
Corresponding author:

${ }^{1}$ Institute of International Relations of Kyiv National Taras Shevchenko University, Ukraine.

E-mail: aisch@ukr.net

ORCID: https://orcid.org/0000-0002-2493-4284

ResearcherID: AAB-8575-2019

${ }^{2}$ Institute of International Relations of Kyiv National Taras Shevchenko University, Ukraine.

E-mail: ritaz@ukr.net

ORCID: https://orcid.org/0000-0001-7174-8946

ResearcherID: AAB-8632-2019

${ }^{3}$ Institute of International Relations of Kyiv National Taras Shevchenko University, Ukraine.

E-mail: alxcv@ukr.net

ORCID: https://orcid.org/0000-0003-3315-2919

ResearcherID: AAB-7820-2019
} 
both on traditional factors and institutions constituting a national economic model. More attention is usually paid to formal rules. They determine a range of possible behavioral patterns of economic entities and thus affect a potential for development of a national economy.

This paper aims at finding institutional factors which are important for services exports in case of the Central and Eastern European countries. First, we provide a review of the previous research related to the role of institutional factors for international trade. Next, the main trends in services exports of the countries are specified. The section devoted to methodology provides specification of regression models, algorithm for selecting variables and the link to the previous research findings. The dependent variables include services exports growth rate and the exports growth in \% of GDP. The independent variables include institutional indicators and several other control variables.

The next section describes our multi-country empirical models for the region based on the data after the crisis of 2008-2009. We compare the models for services and goods exports, and the models for various types of services (industry-specific approach). The use of various model specifications and different samples enabled us to assess robustness of research findings and to determine the main institutional factors of services exports. Finally we use the regression models to estimate how much the services exports of Ukraine can grow if it reaches the institutional development level which is typical for the EU Member States in Central Europe.

\section{Previous research review}

Researchers of economic development and international trade often consider the role of institutions for the operation of markets. It is widely accepted that national institutions determine growth trends in many countries (Acemoglu et al., 2005; Perugini et al., 2017; Álvarez et al., 2018). Well-developed institutions decrease transaction costs of market participants and thus raise the efficiency of the latter. It happens through various channels. In particular, institutions:

- decrease information asymmetry because they provide information about market conditions, goods and market participants;

- decrease risks because institutions establish and ensure property rights and contracts by specifying who should receive returns, how much and when;

- limit the power of politicians and interest groups by ensuring their accountability to the public.

In order to assess the quality of institutions, Kaufmann et al. (2007) used several indicators: government effectiveness, regulatory quality, rule of law (absence of crime, fairness of judicial process, enforceability of contracts), control of corruption (the latter measures the extent to which public power is exercised for private gain), etc.
Several other researchers apply other institutional quality indicators in gravity models. Anderson et al., (2002) used the survey of opinion of businessmen who participated in the World Economic Forum. They had been asked about efficiency of contract enforcement and the level of corruption. The finding was that low quality institutions affect trade very negatively.

Nevertheless, the theoretical analysis of the effect of institutional quality for international trade development is less widespread. Some publications emphasize that good institutional environment stimulates bilateral trade in goods and services because it ensures equal competition conditions for economic entities (Yushi et al., 2018; Araujo et al., 2012). De Groot et al. (2004), Gómez-Herrera (2013) demonstrated that institutional quality and efficient trade policy facilitate bilateral trade relations, while underdeveloped or inadequate institutions can deter trade as much as tariffs do (Francois et al., 2013).

Other researchers also analyze the relationship between foreign trade and efficiency of national institutions. E.g. Donaubauer et al., (2015) analyzed how various types of infrastructure affect competitiveness of companies in the world markets. Fink et al. (2005) proved that communication costs are more important in case of differentiated products unlike in case of trade in homogeneous and consumers goods.

Francois et al. (2013) used the bilateral trade data in 1998-2003 to prove the impact of infrastructure and institutions on international trade. The authors considered preferential tariffs and correlation between GDP, infrastructure and institutional development level. Exports of developing economies turned out to depend more on infrastructure than on regulatory trade barriers. Similarly, Djankov et al. (2006) found that inland transport and the related time delays are the main factors that influence competitiveness of exporters.

Jansen and Nordas (2004) analyzed the effects of institutions, trade policy and infrastructure within two approaches. The first one considered the overall foreign trade, while the second approach was based on analyzing structure of trade (gravity models). According to the first approach the institutional variables positively affect trade flows, while domestic trade barriers largely do not influence foreign trade. But the interaction effect between trade barriers and institutions is negative. This means that the effect of lowering barriers for openness is larger under higher quality of institutions. Therefore institutions provide a double impact: the direct one on the openness and the indirect one through raising the magnitude of the influence of changes in trade barriers on openness of the economy.

It is also worth noting specific types of institutions affecting trade, e.g. low trust in government policy decreases bilateral trade in Europe (Guiso et al., 2009), while efficient legislation and informal institutions facilitate development of international 
trade (Beugelsdijk, de Haan, 2015). Nunn et al. (2013) emphasize interaction between trade and institutions. They provide an evidence for the effect of international trade for domestic institutions, in particular through the value chains within the global production networks and contract enforcement. According to their findings quality of institutions is one of the main sources of benefits from participation in international trade.

According to Zablotska (2008), rising importance of services at the modern stage of world economy development can be explained by expanding production of services beyond national and regional markets. The current global trends include geographical and functional integration of production, distribution and consumptions by creating comprehensive networks which include flows of raw materials, components and final products, and information, which raises the role of services in managing trade flows. Establishment of new institutions takes place. These institutions do not directly participate in production and retail trade, but they are responsible for managing these flows.

Development of institutions is especially important for the services sector because services are important for production fragmentation (Beverelli et al., 2015). Regulatory institutions and contract enforcement institutions are supposed to play the key role, because the services sector interacts with other sectors of economy in a more sophisticated way and is more prone to market uncertainty under information asymmetries.

Amin et al (2006) used regression analysis to study trade flows of 141 countries. They concluded that countries with a more developed institutional structure have a larger and faster growing services sector.

Fiorini etal. (2018) analyzed services tradeliberalization under transformation of regulatory institutions of integration blocs. They claim that efficient liberalization of services trade depends on regulatory quality in the member states of a bloc. Enhancing regulatory institutions is a necessary precondition for deeper coverage of services within trade agreements, which can increase benefits from services trade liberalization.

\section{Modern trends in services exports of the Central and Eastern European countries}

The Central and Eastern European (CEE) countries (including the Baltic states) experienced various (usually positive) trends in services exports growth in 2011-2017 (see table 1). This growth turned out to be more stable than growth of the goods exports. The latter decreased in some countries due to the falling energy prices and direct or indirect effect of the hybrid war of Russia with Ukraine and the related sanctions. Ukraine was an exception, as both its goods and services exports decreased almost equally.

Table 1

6-year exports growth in the CEE countries, 2011-2017, \%

\begin{tabular}{|l|c|c|c|c|c|c|}
\hline \multicolumn{1}{|c|}{ Country } & Goods & Services & $\begin{array}{c}\text { Transport } \\
\text { services }\end{array}$ & $\begin{array}{c}\text { International } \\
\text { tourism, receipts }\end{array}$ & $\begin{array}{c}\text { ICT service } \\
\text { exports }\end{array}$ & $\begin{array}{c}\text { Insurance and } \\
\text { financial services }\end{array}$ \\
\hline Albania & -6 & 15 & -16 & 12 & -9 & -52 \\
\hline Armenia & 67 & 47 & 31 & 50 & 108 & 32 \\
\hline Azerbaijan & -55 & 54 & 26 & 114 & -11 & 139 \\
\hline Belarus & -30 & 40 & -1 & 52 & 218 & 51 \\
\hline Bosnia and Herzegovina & 26 & 11 & 26 & 24 & 22 & 97 \\
\hline Bulgaria & 15 & 19 & 32 & 9 & 54 & -44 \\
\hline Croatia & 22 & 17 & -5 & 16 & 51 & 92 \\
\hline The Czech Republic & 6 & 10 & 6 & -14 & 65 & -1 \\
\hline Estonia & -6 & 22 & -7 & 71 & 55 & 13 \\
\hline Georgia & 11 & 98 & 20 & 178 & 130 & -26 \\
\hline Hungary & -3 & 21 & 36 & 17 & 31 & 32 \\
\hline Latvia & 11 & 15 & 4 & 40 & 173 & -23 \\
\hline Lithuania & 8 & 69 & 78 & 20 & 261 & 52 \\
\hline Moldova & 7 & 25 & 14 & 74 & 5 & -31 \\
\hline Montenegro & -34 & 25 & 40 & 20 & 33 & 37 \\
\hline North Macedonia & 38 & 12 & 8 & 37 & 19 & 29 \\
\hline Poland & 24 & 44 & 43 & 21 & 147 & 28 \\
\hline Romania & 16 & 94 & 123 & 49 & 158 & 10 \\
\hline Russian Federation & -31 & -1 & 14 & -12 & 50 & 2 \\
\hline Serbia & 41 & 41 & 42 & 48 & 135 & -10 \\
\hline Slovak Republic & 6 & 43 & 41 & 19 & 142 & 65 \\
\hline Slovenia & 10 & 19 & 29 & 0 & 19 & -30 \\
\hline Turkey & 17 & 7 & 37 & 5 & -31 & 40 \\
\hline Ukraine & -36 & -33 & -36 & -63 & 165 & -76 \\
\hline Sorces: Wor & & & & & \\
\hline
\end{tabular}

Sources: World Development Indicators and authors' calculations 
In the analyzed period various countries were the regional leaders by exports growth: Romania (transport services), Georgia (tourism services), Lithuania (information and communication technologies (ICT) services), Azerbaijan (financial and insurance services), Armenia (goods exports). ICT services exports showed the most prominent increase in several countries, especially considering the lower starting base level. In Ukraine it was the only services sector that demonstrated exports growth.

\section{Methodology and preliminary analysis}

Most researchers who analyze the role of institutions for trade use the Eurobarometer trust indicators, the World Bank institutional indicators and alternative data on institutional quality and governance (De Groot et al., 2004; Linders et al., 2005; Francois and Manchin, 2013). We use the institutional indicators provided by the World Bank and the Heritage Foundation.

The country-specific models, provided by Zablotska (2009), were developed for the CEE countries in the period before the crisis in 2008-2009. The depended variable was the absolute value of services exports of each country. Besides institutional indicators (regulatory quality, rule of law, control of corruption and economic freedom indices) the independent variables included GDP per capita. Institutions turned out to have a different effect in the EU Member States and Non-Member States in the CEE region. Economic development level significantly influenced services exports in all the analyzed countries. Institutional development (in particular better economic freedom and regulatory quality) usually influenced services exports more in the Eastern Europe (Non-Member States), where the values of institutional variables were lower. In the Central Europe (the EU Member States), where the values of institutional variables were higher, the regression coefficients varied from negative to positive ones. A possible explanation was the problem of endogeneity related to the GDP per capita variable. E.g. under higher institutional quality institutions could affect economic growth more than they would influence services exports.

In this paper we estimated the effect of institutional variables on export competitiveness within a 6-year post-crisis period by using multi-country models and by analyzing a larger set of institutional variables. The initial specification of the tested models was designed to control for several non-institutional variables:

$$
\begin{aligned}
& E x p=b_{0}+b_{1} L a b o r+b_{2} \ln (G D P)+ \\
& +b_{3} \ln (G D P p c)+\Sigma b_{i} \Delta E F+\Sigma b_{j} \Delta W G I,
\end{aligned}
$$

Exp is a 6-year exports growth for services, specific types of services or goods during 2011-2017, \%. Labor growth of a total labor force in 201-2017, \%. GDP - gross domestic product in 2014, US dollars (current prices, exchange rate method). GDPpc - gross domestic product per capita in 2014, US dollars (current prices, exchange rate method). The above-mentioned variables are taken from World Development Indicators / World Bank (2019).

$E F-$ a set of economic freedom variables from Index of Economic Freedom / The Heritage Foundation (2019), score $(\min 0, \max 100)$. WGI - a set of governance variables from Worldwide Governance Indicators / World Bank (2019), score (min -2.5, max 2.5). $\Delta$ means the increase during the 6-year period in 2011-2017.

But according to the correlation analysis results (see table 2), labor force growth was significantly related only to the ICT services exports growth (in a sample consisting of the $24 \mathrm{CEE}$ countries) and the correlation was negative. No significant correlation was found with the export indicators in a larger sample consisting of the all countries in the world with a published data. Neither GDP nor GDP per capita affected exports growth in the CEE countries. But if we consider all the countries of the world, larger economies tended to have slower growth of goods exports (significant negative correlation -0.21) and tourism services exports (-0.16). Also more advanced economies tended to have lower growth of exports of goods $(-0.33)$ and financial and insurance services $(-0.16)$.

The progress by the overall economic freedom index had no impact on exports growth in the world, but it positively affected the ICT services exports in the CEE countries. Inside the group of the CEE countries, those countries which were the EU Member States tended to have on average $40 \%$ faster ICT services exports growth during the 6 years period (but the difference is statistically insignificant according to the $\mathrm{t}$-test for difference in the means, and only the Mann-Whitney $U$ Test showed a marginal statistical significance).

Within the correlation analysis we also applied a robustness check by using a weighted enlarged sample, which included all the countries of the world with available data. Weight 7 is assigned to CEE countries, weight 1 to the rest of the countries. Thus, the values for CEE countries (small sample) and for other countries contributed roughly equally to the calculation of the correlations in order to select proper variables for the regression analysis.

If the absolute scores for institutional variable are used instead of their increases, a similar check results in marking positive correlations of goods exports growth with investment freedom (0.49); and tourism services growth with (low) government spending (0.40) and with labor freedom (0.42).

Regression analysis is applied with the selected dependent variables for each of the 6 exports growth indicators. The initial models are calculated for the sample consisting of the $24 \mathrm{CEE}$ countries. The robustness check is made by:

- excluding outliers (standardized residuals >+/2.5 standard deviations); 
Vol. 5, No. 5, 2019

Baltic Journal of Economic Studies

Table 2

Correlation matrix for exports growth and independent variables in the CEE countries

\begin{tabular}{|l|c|c|c|c|c|c|}
\hline & Goods & Services & $\begin{array}{c}\text { Transport } \\
\text { services }\end{array}$ & $\begin{array}{c}\text { International } \\
\text { tourism, receipts }\end{array}$ & $\begin{array}{c}\text { ICT service } \\
\text { exports }\end{array}$ & $\begin{array}{c}\text { Insurance and } \\
\text { financial services }\end{array}$ \\
\hline Labour & -0.14 & 0.01 & 0.14 & 0.08 & $-0.44^{*}$ & 0.17 \\
\hline Ln(GDP) & -0.20 & -0.14 & 0.17 & -0.39 & 0.10 & 0.06 \\
\hline Ln(GDPpc) & -0.13 & 0.01 & 0.26 & $-0.28^{*}$ & 0.13 & 0.27 \\
\hline Economic freedom & -0.20 & 0.17 & -0.06 & 0.30 & $0.43^{*}$ & -0.03 \\
\hline Property rights & -0.02 & 0.10 & 0.00 & 0.14 & 0.00 & 0.23 \\
\hline Government integrity & -0.05 & 0.33 & -0.05 & 0.38 & $0.47^{*}$ & 0.02 \\
\hline Tax burden (lower) & -0.24 & 0.05 & 0.03 & 0.13 & 0.22 & -0.01 \\
\hline Government spending (lower) & -0.10 & 0.23 & -0.05 & 0.24 & $0.45^{*}$ & -0.30 \\
\hline Business freedom & -0.25 & -0.33 & -0.39 & -0.21 & 0.07 & -0.39 \\
\hline Labor freedom & 0.23 & -0.12 & 0.06 & -0.25 & 0.07 & -0.11 \\
\hline Monetary freedom & 0.24 & $0.40^{*}$ & $0.53^{*}$ & 0.15 & 0.19 & 0.12 \\
\hline Trade freedom & -0.27 & -0.25 & -0.28 & -0.22 & -0.06 & -0.34 \\
\hline Investment freedom & -0.11 & -0.14 & -0.26 & 0.06 & -0.24 & -0.31 \\
\hline Financial freedom & 0.03 & -0.03 & -0.08 & 0.20 & -0.22 & 0.16 \\
\hline Voice and accountability & 0.01 & $0.36^{*}$ & -0.15 & 0.31 & $0.55^{*}$ & -0.28 \\
\hline $\begin{array}{l}\text { Political stability and absence } \\
\text { of violence / terrorism }\end{array}$ & 0.20 & 0.24 & 0.07 & $0.32^{*}$ & -0.14 & 0.19 \\
\hline Government effectiveness & -0.49 & 0.02 & -0.25 & 0.13 & $0.33^{*}$ & -0.02 \\
\hline Regulatory quality & -0.28 & 0.08 & -0.38 & 0.25 & $0.41^{*}$ & -0.28 \\
\hline Rule of law & -0.07 & $0.49^{*}$ & 0.03 & $0.52^{*}$ & $0.40^{*}$ & 0.02 \\
\hline Control of corruption (low corruption) & $-0.38^{*}$ & $0.39^{*}$ & -0.17 & 0.42 & $0.40^{*}$ & -0.04 \\
\hline Notes, Instityon varb are
\end{tabular}

Notes. Institutional variables are measured as increases of score with the higher score meaning improvement of economic freedom or governance. Correlations $>0.33$ are significant at $\mathrm{p}<0.1,>0.40$ at $\mathrm{p}<0.05$. ${ }^{*}$ if significant or marginally significant correlations for the CEE countries remain significant at $\mathrm{p}<0.01$ for the weighted enlarged sample.

Sources: authors' calculations based on World Development Indicators, Index of Economic Freedom and Worldwide Governance Indicators.

- using the aforecited weighted extended sample;

- using alternative measurement of the dependent variable based on the formula:

$Y=\left(\operatorname{Exp}_{2017}{ }^{*} 100 \% / G D P_{2017}\right)-$

- $\left(\operatorname{Exp}_{2011}{ }^{*} 100 \% / G D P_{2011}\right)$,

\section{Results}

The table 3 shows that services exports growth depends positively on growth of monetary freedom, rule of law, voice and accountability. Better control of corruption also may help to increase exports competitiveness, although its effect may not be distinguished from the improvement of the general rule of law.

We further analyze the main components of services exports. Export competitiveness of the transport services is positively related only to improvement of monetary freedom (see table 4). The effect is statistically robust, although the transmission mechanism is not very clear in this case. But it is possible to state that transport services can be fostered by a more stable currency and market-determined prices (including lower inflation and avoiding price controls).

Tourism services exports are positively affected by enhancing the rule of law (see table 5). We assume that the latter may have two possible effects: better safety for tourists, stimulating them to arrive (demand effect) and better legal environment for providers of services (supply effect). Several other institutional variables may influence tourism exports competitiveness: smaller size of economy, improvement of political stability and absence of violence / terrorism / wars / social conflicts, decrease in corruption, and better labor freedom (ability of businesses to contract employees freely and to dismiss redundant workers, low wage controls / other labor constraints), but their effect is not robust.

Growth of voice and accountability (democracy and political freedom) is the main institutional variable affecting competitiveness of ICT services exporters (see table 6). Several other indicators also may influence it, but their effects are not robust, and therefore additional studies are necessary before making policy recommendations. In particular, ICT services exports may be positively affected by improving government integrity (absence of bribery, nepotism, cronyism, embezzlement, excessive regulations etc.), government effectiveness (quality of health and education, infrastructure, public services, civil service, policy implementation etc.) and decreasing government spending. On the other hand, faster growth of the total labor force is correlated with lower ICT exports growth. The relationship seems to be contradictory as better supply of labor can provide the ICT industry with a cheaper labor. A possible explanation can be 
Table 3

Models for services exports growth

\begin{tabular}{|c|c|c|c|c|c|c|c|}
\hline Coefficient / sample & CEE & Extended & CEE & Extended & CEE, alt. Y & CEE, alt. Y & CEE, alt. Y \\
\hline Y-intercept & $\begin{array}{c}20.5^{* * *} \\
(5.5)\end{array}$ & $\begin{array}{c}27.7^{* * *} \\
(3.0)\end{array}$ & $\begin{array}{c}25.8^{* * *} \\
(5.5)\end{array}$ & $\begin{array}{c}29.5^{* * *} \\
(2.9)\end{array}$ & $\begin{array}{l}3.0^{* * *} \\
(0.51)\end{array}$ & $\begin{array}{l}3.2^{* * *} \\
(0.57)\end{array}$ & $\begin{array}{l}2.4^{* * *} \\
(0.56)\end{array}$ \\
\hline Monetary freedom & $\begin{array}{l}1.47^{* *} \\
(0.66)\end{array}$ & $\begin{array}{l}0.82^{* *} \\
(0.33)\end{array}$ & $\begin{array}{l}1.81^{* *} \\
(0.69)\end{array}$ & $\begin{array}{c}0.94^{* * *} \\
(0.33)\end{array}$ & & $\begin{array}{l}0.138^{*} \\
(0.071)\end{array}$ & $\begin{array}{l}0.146^{* *} \\
(0.065)\end{array}$ \\
\hline Rule of law & $\begin{array}{l}69.1^{* *} \\
(24.8)\end{array}$ & $\begin{array}{c}41.5^{* * *} \\
(12.7)\end{array}$ & & & $8.43^{* * *}(2.49)$ & & \\
\hline Voice and accounting & & & $\begin{array}{l}56.9^{* *} \\
(23.3)\end{array}$ & $\begin{array}{c}38.5^{* * *} \\
(11.2)\end{array}$ & & $\begin{array}{l}6.10^{* *} \\
(2.40)\end{array}$ & \\
\hline Control of corruption & & & & & & & $\begin{array}{l}6.58^{* * *} \\
(1.94)\end{array}$ \\
\hline $\mathrm{R}^{2}$ & 0.39 & 0.06 & 0.35 & 0.06 & 0.34 & 0.30 & 0.41 \\
\hline $\mathrm{p}$ & 0.006 & 0.000 & 0.011 & 0.000 & 0.003 & 0.025 & 0.004 \\
\hline $\mathrm{N}$ & 24 & $300^{\wedge}$ & 24 & $300^{\wedge}$ & 24 & 24 & 24 \\
\hline
\end{tabular}

Notes. Institutional variables are measured as increases of score unless otherwise specified. B-coefficient significance: ${ }^{*}$ at $\mathrm{p}<0.1,{ }^{* *}$ at $\mathrm{p}<0.05$, ** at $\mathrm{p}<0.01$ according to the $\mathrm{t}$-test. ${ }^{\wedge}$ means multiple counting of cases because of weighting.

Sources: authors' calculations based on World Development Indicators, Index of Economic Freedom and Worldwide Governance Indicators.

Table 4

Models for transport services exports growth

\begin{tabular}{|c|c|c|c|c|}
\hline Coefficient / sample & CEE & CEE excluding Romania & Extended & CEE, alt. Y \\
\hline Y-intercept & $\begin{array}{c}17.0^{* *} \\
(6.2)\end{array}$ & $\begin{array}{c}14.6^{* *} \\
(4.6)\end{array}$ & $\begin{array}{c}20.5^{* * *} \\
(3.0)\end{array}$ & $\begin{array}{c}0.44^{*} \\
(0.23)\end{array}$ \\
\hline \multirow{2}{*}{ Monetary freedom } & $\begin{array}{c}2.22^{* * *} \\
(0.77)\end{array}$ & $\begin{array}{c}1.81^{* * *} \\
(0.58)\end{array}$ & $\begin{array}{c}1.41^{* * *} \\
(0.34)\end{array}$ & $\begin{array}{c}0.066^{* *} \\
(0.028)\end{array}$ \\
\hline $\mathrm{R}^{2}$ & 0.28 & 0.32 & 0.06 & 0.20 \\
\hline $\mathrm{p}$ & 0.008 & 0.005 & 0.000 & 0.028 \\
\hline $\mathrm{N}$ & 24 & 23 & $295^{\wedge}$ & 24 \\
\hline
\end{tabular}

Notes. Institutional variables are measured as increases of score unless otherwise specified. B-coefficient significance: ${ }^{*}$ at $\mathrm{p}<0.1,{ }^{* *}$ at $\mathrm{p}<0.05$, ** at $\mathrm{p}<0.01$ according to the $\mathrm{t}$-test. ${ }^{\wedge}$ means multiple counting of cases because of weighting.

Sources: authors' calculations based on World Development Indicators, Index of Economic Freedom and Worldwide Governance Indicators.

Table 5

Models for tourism services exports growth

\begin{tabular}{|c|c|c|c|c|c|}
\hline Coefficient / sample & CEE & $\begin{array}{c}\text { CEE excluding } \\
\text { Georgia }\end{array}$ & Extended & CEE, alt. Y & CEE, alt. Y \\
\hline Y-intercept & $\begin{array}{c}25.3^{* * *} \\
(8.7)\end{array}$ & $\begin{array}{c}23.4^{* * *} \\
(7.3)\end{array}$ & $\begin{array}{c}132.4^{* *} \\
(63.8)\end{array}$ & $\begin{array}{l}1.2^{* *} \\
(0.51)\end{array}$ & $\begin{array}{l}1.2^{* *} \\
(0.53)\end{array}$ \\
\hline $\operatorname{Ln}(\mathrm{GDP})$ & & & $\begin{array}{l}-5.35^{* *} \\
(2.41)\end{array}$ & & \\
\hline Rule of law & $\begin{array}{c}119.8^{* * *} \\
(42.4)\end{array}$ & $\begin{array}{l}67.0^{*} \\
(38.9)\end{array}$ & $\begin{array}{l}50.2^{* *} \\
(21.9)\end{array}$ & $\begin{array}{l}7.13^{* * *} \\
(2.49)\end{array}$ & \\
\hline $\begin{array}{c}\text { Political stability and absence of } \\
\text { violence/terrorism }\end{array}$ & & & $\begin{array}{l}36.4^{* * *} \\
(10.74)\end{array}$ & & \\
\hline Labor freedom (score in 2014) & & & $\begin{array}{l}0.658^{* *} \\
(0.302)\end{array}$ & & \\
\hline Control of corruption & & & & & $\begin{array}{l}5.28^{* *} \\
(2.01)\end{array}$ \\
\hline $\mathrm{R}^{2}$ & 0.27 & 0.12 & 0.12 & 0.27 & 0.24 \\
\hline $\mathrm{p}$ & 0.010 & 0.100 & 0.000 & 0.009 & 0.015 \\
\hline $\mathrm{N}$ & 24 & 23 & $295^{\wedge}$ & 24 & 24 \\
\hline
\end{tabular}

Notes. Institutional variables are measured as increases of score unless otherwise specified. B-coefficient significance: ${ }^{*}$ at $\mathrm{p}<0.1,{ }^{* *}$ at $\mathrm{p}<0.05$, ** at $\mathrm{p}<0.01$ according to the $\mathrm{t}$-test. ${ }^{\wedge}$ means multiple counting of cases because of weighting.

Sources: authors' calculations based on World Development Indicators, Index of Economic Freedom and Worldwide Governance Indicators. 
a development of labor-intensive industries, which can compete for other production factors with the ICT services providers. But in any case, the effect is not robust and can be traced only in the extended sample.

Unlike the previously discussed services, we were not able to find any significant factors affecting export competitiveness of financial and insurance services. Therefore, no model is provided for them in this paper.

It is also reasonable to compare the influence of institutional variables on trends in exports of goods and services (see table 7). A positive influence of corruption on goods exports growth seems to contradict theoretical assumptions. Therefore, additional studies are necessary, especially considering that goods are also a very heterogeneous group, and the effect may mask several industry-specific effects. The next factor is investment freedom (low restrictions on the movement of capital across the border and within a country) affecting goods export positively. Other effects are not statistically robust. In particular, there may be a possible effect of improving voice and accountability. And goods exports seem to grow faster in less developed economies.

We further use the models to calculate the effect for services exports caused by a potential institutional progress in Ukraine (in monetary stability, rule of law and voice and accountability) to the level in Poland and Latvia used as a benchmark level (see table 8).

Table 6

Models for ICT services exports growth

\begin{tabular}{|c|c|c|c|c|c|c|}
\hline Coefficient / sample & CEE & CEE & Extended & Extended & Extended & CEE, alt. Y \\
\hline Y-intercept & $\begin{array}{l}90.1^{* * *} \\
(13.8)\end{array}$ & $\begin{array}{l}59.4^{* * *} \\
(18.2)\end{array}$ & $\begin{array}{c}82.3^{* * *} \\
(6.4)\end{array}$ & $\begin{array}{c}63.4^{* * *} \\
(5.8)\end{array}$ & $\begin{array}{c}72.0^{* * *} \\
(7.2)\end{array}$ & $\begin{array}{c}0.68^{* * *} \\
(0.11)\end{array}$ \\
\hline Voice and accountability & $\begin{array}{c}194.7^{* * *} \\
(62.5)\end{array}$ & & $\begin{array}{c}106.0^{* * *} \\
(24.6)\end{array}$ & $\begin{array}{c}117.4^{* * *} \\
(25.1)\end{array}$ & & $\begin{array}{l}1.11^{* *} \\
(0.51)\end{array}$ \\
\hline Labor force growth & & & $\begin{array}{c}-1.54^{* * *} \\
(0.58)\end{array}$ & & $\begin{array}{l}-1.34^{* *} \\
(0.60)\end{array}$ & \\
\hline Overall economic freedom index & & $\begin{array}{l}9.10^{* *} \\
(4.11) \\
\end{array}$ & & & $\begin{array}{c}4.64^{* * *} \\
(1.36)\end{array}$ & \\
\hline Government integrity & & & & & $\begin{array}{c}117.8^{* * *} \\
(24.2)\end{array}$ & \\
\hline Government spending (low) & & & $\begin{array}{l}1.67^{* * *} \\
(0.44)\end{array}$ & & & \\
\hline Government effectiveness & & & & $\begin{array}{l}62.5^{* * *} \\
(21.2)\end{array}$ & & \\
\hline $\mathrm{R}^{2}$ & 0.31 & 0.18 & 0.19 & 0.13 & 0.18 & 0.18 \\
\hline $\mathrm{p}$ & 0.005 & 0.037 & 0.000 & 0.000 & 0.000 & 0.038 \\
\hline $\mathrm{N}$ & 24 & 24 & $278^{\wedge}$ & $287^{\wedge}$ & $278^{\wedge}$ & 24 \\
\hline
\end{tabular}

Notes. Institutional variables are measured as increases of score unless otherwise specified. B-coefficient significance: ${ }^{*}$ at $\mathrm{p}<0.1,{ }^{* *}$ at $\mathrm{p}<0.05$, ** at $\mathrm{p}<0.01$ according to the t-test. ${ }^{\wedge}$ means multiple counting of cases because of weighting.

Sources: authors' calculations based on World Development Indicators, Index of Economic Freedom and Worldwide Governance Indicators.

Table 7

Models for goods exports growth

\begin{tabular}{|c|c|c|c|c|}
\hline Coefficient / sample & $\mathrm{CEE}$ & CEE excluding Armenia & Extended & CEE, alt. Y \\
\hline Y-intercept & $\begin{array}{l}-36.3^{*} \\
(18.3)\end{array}$ & $\begin{array}{l}-35.2^{* *} \\
(14.2)\end{array}$ & $\begin{array}{c}138.5^{* * *} \\
(17.9)\end{array}$ & $\begin{array}{l}1.8 \\
(1.3)\end{array}$ \\
\hline $\operatorname{Ln}(\mathrm{GDPpc})$ & & & $\begin{array}{c}-18.4^{* * *} \\
(2.1)\end{array}$ & \\
\hline Control of corruption & $\begin{array}{l}-35.5^{*} \\
(19.3)\end{array}$ & $\begin{array}{l}-46.5^{* * *} \\
(15.2)\end{array}$ & & $\begin{array}{c}-13.2^{* *} \\
(4.9)\end{array}$ \\
\hline $\begin{array}{l}\text { Investment freedom } \\
\text { (score in 2014) }\end{array}$ & $\begin{array}{l}0.670^{* *} \\
(0.261)\end{array}$ & $\begin{array}{c}0.622^{* * *} \\
(0.203)\end{array}$ & $\begin{array}{c}0.688^{* * *} \\
(0.098)\end{array}$ & \\
\hline Voice and accountability & & & & $\begin{array}{l}3.71^{* *} \\
(1.65)\end{array}$ \\
\hline $\mathrm{R}^{2}$ & 0.35 & 0.52 & 0.23 & 0.41 \\
\hline $\mathrm{p}$ & 0.011 & 0.001 & 0.000 & 0.004 \\
\hline $\mathrm{N}$ & 24 & 23 & $301^{\wedge}$ & 24 \\
\hline
\end{tabular}

Notes. Institutional variables are measured as increases of score unless otherwise specified. B-coefficient significance: ${ }^{*}$ at $\mathrm{p}<0.1{ }^{* *}$ at $\mathrm{p}<0.05$, ** at $\mathrm{p}<0.01$ according to the t-test. ${ }^{\wedge}$ means multiple counting of cases because of weighting.

Sources: authors' calculations based on World Development Indicators, Index of Economic Freedom and Worldwide Governance Indicators. 
Table 8

Institutional variables in the selected CEE countries.

\begin{tabular}{|l|c|c|c|}
\hline & $\begin{array}{c}\text { Monetary } \\
\text { freedom }(\min \\
\text { 0, max 100), } \\
2019\end{array}$ & $\begin{array}{c}\text { Rule of law } \\
(\min -2.5, \\
\max 2.5), \\
2018\end{array}$ & $\begin{array}{c}\text { Voice and } \\
\text { accountability } \\
(\min -2.5, \max \\
2.5), 2018\end{array}$ \\
\hline Belarus & 67 & -0.83 & -1.35 \\
\hline Czech Republic & 81.5 & 1.05 & 0.93 \\
\hline Georgia & 76 & 0.33 & 0.25 \\
\hline Hungary & 81.8 & 0.56 & 0.32 \\
\hline Latvia & 81.1 & 0.96 & 0.81 \\
\hline Moldova & 73.5 & -0.41 & -0.11 \\
\hline Poland & 82.1 & 0.43 & 0.72 \\
\hline Romania & 82.7 & 0.33 & 0.46 \\
\hline Russia & 65.1 & -0.82 & -1.06 \\
\hline Turkey & 70.0 & -0.32 & -0.83 \\
\hline Ukraine & 58.6 & -0.72 & -0.01 \\
\hline
\end{tabular}

Sources: Index of Economic Freedom and Worldwide Governance Indicators.

Raising monetary stability may result in growth of transport services exports of Ukraine by additional $31-52 \%$ or $1.55 \%$ GDP depending on a specification of the models. Improving the rule of law can lead to increase of tourism services exports by $58-202 \%$ or 8-12\% GDP. Enhancing voice and accountability may bring about an additional ICT services exports growth by $77-160 \%$ or $0.8-0.9 \%$ GDP.

\section{Conclusions}

Under transition to a new economic model, the effect of traditional economic growth factors depends on the quality of new institutions and enhancing their influence on motivation. The latter also depends on the development level of political system, which establishes the institutional framework of a new economic model.

The Central and Eastern European countries experienced various trends in services exports growth in 2011-2017, but this growth turned out to be more stable than the goods exports growth. The multi-country models for services export competitiveness showed that institutional improvements may have a positive effect. Meanwhile the institutional development level rarely influenced the services exports growth at least in the medium run.

There are three main factors affecting competitiveness of services exports from the Central and Eastern European countries. Each of them influences a particular industry. Monetary freedom (currency stability and market-based prices) stimulates exports of transport services. The rule of law (including such issues as contract enforcement, property rights, efficiency of police and courts, absence of crime and violence etc.) is important for raising international tourism receipts. ICT exports depend primarily on voice and accountability, i.e. the way a country follows democratic principles, respects human rights and has free media. As for financial and insurance services exports, no significant institutional factor was found. Thus, industry specific approach accounting for services heterogeneity provides better understanding of the transmission mechanism affecting the competitiveness.

Several other institutional factors also may be important (control of corruption, political stability, labor freedom, government integrity, government effectiveness and lower government size), but their effect is not robust or cannot be distinguished from the effect of the above said factors. Fighting corruption may have positive results for services exports unlike in case of goods exports, although additional studies are necessary to describe the effects. On the other hand, investment freedom is less important for competitiveness of services exports than in case of goods exports.

Using Poland and Latvia (two of the EU Member States in the CEE region) as a benchmarking level and the developed regression models enabled us to estimate a potential effect of institutional progress in Ukraine if it implements affordable European institutional standards and practice. In particular, it can boost transport, tourism, information and communication technologies services exports by $30-200 \%$ or by $10-15 \%$ of its GDP.

\section{Acknowledgements}

This publication was prepared with the support of the Erasmus+ Program of the European Union (Jean Monnet Centre of Excellence Project № 611625-EPP1-2019-1-UA-EPPJMO-CoE "Advancing European Studies in Ukraine: Interdisciplinary Approach").

The European Commission's support for the production of this publication does not constitute an endorsement of the contents, which reflect the views only of the authors, and the Commission cannot be held responsible for any use which may be made of the information contained therein.

\section{References:}

Acemoglu, D., Johnson, S., \& Robinson, J. A. (2005). Institutions as a Fundamental Cause of Long-Run Growth, in P. Aghion and S. N. Durlauf (eds). Handbook of Economic Growth, vol. 1A. Amsterdam: Elsevier North-Holland, pp. 385-472.

Álvarez, I., Barbero, J., Rodríguez-Pose, A., \& Zofío, J. (2018). Does Institutional Quality Matter for Trade? Institutional Conditions in a Sectoral Trade Framework. World Development, vol. 103, pp. $72-87$.

Amin, M., \& Mattoo, A. (2006). Do Institutions Matter More for Services? Policy, Research working paper no. WPS 4032. Washington, DC: World Bank. Retrieved from: http://documents.worldbank.org/curated/ en/262251468328180138/Do-institutions-matter-more-for-services (accessed 15 September 2018). 
Anderson, J., \& Marcouille D. (2002). Insecurity and the Pattern of Trade: An Empirical Investigation. The Review of Economics and Statistics, vol. 84, pp. 342-352.

Araujo, L., Mion, G., \& Ornelas, E. (2012). Institutions and Export Dynamics. CEP Discussion Paper, no. 1118,49 p. Retrieved from: http://cep.lse.ac.uk/pubs/download/dp1118.pdf (accessed 15 June 2018).

Beverelli, C., Fiorini, M., \& Hoekman, B. (2015). Services Trade Restrictiveness and Manufacturing Productivity: The Role of Institutions. CEPR Discussion Paper No. 10834 and EUI Robert Schuman Centre for Advanced Studies Working Paper 2015/63, 39 p. Retrieved from: https://cadmus.eui.eu/bitstream/handle/1814/36835/ RSCAS_2015_63.pdf?sequence=1 (accessed 10 June 2018).

De Groot, H., Linders, G.-J., Rietveld, P., \& Subramanian, U. (2004). The Institutional Determinants of Bilateral Trade Patterns. Kyklos, Wiley Blackwell, vol. 57, issue 1, pp. 103-123.

Djankov, S., Freund, C., \& Pham, C. (2006). Trading on Time. World Bank policy research working paper no. 3909. Washington DC. Retrieved from: http://documents.worldbank.org/curated/en/761201468175464382/ Trading-on-time (accessed 15 September 2018).

Donaubauer, J., Glas, A., \& Nunnenkamp, P. (2015). Infrastructure and Trade: A Gravity Analysis for Major Trade Categories Using a New Index of Infrastructure. Kiel Institute for the World Economy Working paper, no. 2016,31 p. Retrieved from: https://www.ifw-kiel.de/fileadmin/Dateiverwaltung/IfW-Publications/Peter Nunnenkamp/ infrastructure-and-trade-a-gravity-analysis-for-major-trade-categories-using-a-new-index-of-infrastructure / kwp_2016.pdf (accessed 15 September 2018).

Fink, C., Mattoo, A., \& Neagu, A. (2005). Assessing the Impact of Communication Costs on International Trade. Journal of International Economics, vol. 67, issue 2, pp. 428-445.

Fiorini, M., \& Hoekman B. (2018). Trade Agreements, Regulatory Institutions and Services Liberalization. Global Policy, vol. 9, issue 4, pp. 441-450.

Francois, J., \& Manchin, M. (2013). Institutions, Infrastructure, and Trade. World Development, vol. 46, pp. 165-175.

Gómez-Herrera, E. (2013). Comparing Alternative Methods to Estimate Gravity Models of Bilateral Trade. Empirical Economics, vol. 44, issue 3, pp. 1087-1111.

Guiso, L., Sapienza, P., \& Zingales, L. (2009). Cultural Biases in Economic Exchange? Quarterly Journal of Economics, vol. 124, issue 3, pp. 1095-1131.

Jansen, M., \& Nordas, H. (2004). Institutions, Trade Policy and Trade Flows. WTO Staff Working Paper ESRD-2004-02, 25 p. Retrieved from: https://www.wto.org>reser_e>ersd200402_e (accessed 10 March 2019).

Kaufmann, D., Kraay, A., \& Mastruzzi, M. (2007). Governance Matters VI: Governance Indicators for $1996-2006$. World Bank Policy Research Working Paper, no. 4280, 94 p. Retrieved from: https://ssrn.com/abstract=999979 (accessed 19 October 2018).

Gert-Jan M. Linders, G-J., Slangen, A., de Groot, H., \& Beugelsdijk, S. Cultural and Institutional Determinants of Bilateral Trade Flows. Tinbergen Institute Discussion Paper, TI 2005-074/3, 28 p. Retrieved from: https://papers.tinbergen.nl/05074.pdf (accessed 10 November 2018).

Nunn, N., \& Trefler, D. (2013). Domestic Institutions as a Source of Comparative Advantage. Handbook of International Economics, vol. 4, p. 5. Amsterdam: North Holland, pp. 263-315.

Perugini, C., \& Pompei, F. (2017). Temporary Jobs, Institutions, and Wage Inequality within Education Groups in Central-Eastern Europe. World Development, vol. 92, pp. 40-59.

The Heritage Foundation (2019). Index of Economic Freedom [Online]. Retrieved from: https://www.heritage.org/ index/ (accessed: 10 October 2019).

World Bank (2019). World Development Indicators [Online]. Last Updated: October 2, 2019. Retrieved from: https://datacatalog.worldbank.org/dataset/world-development-indicators (accessed: 10 October 2019).

World Bank (2019). Worldwide Governance Indicators [Online]. Retrieved from: http://info.worldbank.org/ governance/wgi/ (accessed: 10 October 2019).

Yu, S., Beugelsdijk, S., \& de Haan, J. (2015). Trade, Trust and the Rule of Law. European Journal of Political Economy, vol. 37, pp. 102-115.

Yushi, J., \& Borojo, D. (2019). The impacts of institutional quality and infrastructure on overall and intra-Africa trade. Economics E-Journal, Discussion paper, no. 2018-75, 28 p. Retrieved from: http://www.economics-ejournal.org/ economics/journalarticles/2019-10 (accessed 20 April 2019).

Zablotska, R. (2008). The System of Institutional Regulation of World Trade in Services. Kyiv: Kyiv University Press. (in Ukrainian)

Zablotska, R. (2009). Institutsiyne rehulyuvannya mizhnarodnoyi torhivli posluhamy [Institutional Regulation of World Trade in Services]. (Dr. of Sc. (Economics) Thesis). Kyiv: Taras Shevchenko National University of Kyiv. (in Ukrainian) 